\title{
Effects of aging on mitochondrial hydrogen peroxide emission and calcium retention capacity in rat heart
}

\author{
Mi-Hyun No', Jun-Won Heo', Su-Zi Yoo', Han-Sam Jo', Dong-Ho Park', Ju-Hee Kang², Dae-Yun Seo³, Jin Han³, Hyo-Bum Kwak1,* \\ 'Department of Kinesiology, Inha University, Incheon, Korea \\ ${ }^{2}$ Department of Pharmacology and Medicinal Toxicology Research Center, Inha University School of Medicine, Incheon, Korea \\ ${ }^{3}$ Department of Physiology and Cardiovascular and Metabolic Disease Center, Inje University School of Medicine, Busan, Korea
}

Aging is a risk factor for heart disease and heart failure, which result from a progressive impairment of cardiac functions, including stroke volume, cardiac output, blood flow, and oxygen consumption. Age-related cardiac dysfunction is associated with impaired cardiac structures, such as the loss of myocytes, structural remodeling, altered calcium $\left(\mathrm{Ca}^{2+}\right)$ handling, and contractile dysfunction. However, the mechanism by which aging affects mitochondrial function in the heart is poorly understood. The purpose of this study was to determine the effects of aging on mitochondrial function in the rat heart. Male Fischer 344 rats were randomly assigned to very young sedentary (VYS, 1 month), young sedentary (YS, 4 months), middle-aged sedentary (MS, 10 months), and old sedentary (OS, 20 months) groups. mitochondrial complex protein levels and mitochondrial function (e.g., mitochondrial hydrogen perox- ide $\left(\mathrm{H}_{2} \mathrm{O}_{2}\right)$ emission and $\mathrm{Ca}^{2+}$ retention capacity) were analyzed in the left ventricle. Aging was associated with decreased levels of OXPHOS (oxidative phosphorylation) protein expression of complex I to IV in the function of the electron transport chain. Aging increased the mitochondrial $\mathrm{H}_{2} \mathrm{O}_{2}$ emitting potential in the heart. In contrast, mitochondrial $\mathrm{Ca}^{2+}$ retention capacity gradually decreased with age. These data demonstrate that aging impairs mitochondrial function in cardiac muscle, suggesting that mitochondrial dysfunction with aging may be a primary factor for aging-induced cardiac dysfunction in the heart.

Keywords: Aging, Heart, Mitochondrial function, Mitochondrial oxidative phosphorylation

\section{INTRODUCTION}

Aging causes progressive impairment of homeostasis in the human body. In general, aging is affected by environmental changes and can lead to various diseases (Kirkwood, 2005). In particular, the natural process of aging is among the most major risk factors that increase susceptibility to develop cardiovascular diseases (Dai et al., 2012), which often feature left ventricular hypertrophy (Dai and Rabinovitch, 2009), diastolic dysfunction (Bursi et al., 2006), valve degeneration (Karavidas et al., 2010), increased myocardial fibrosis (Olsen et al., 2005), and increased atrial fibrillation (Gerhard-Herman et al., 2017).

Mitochondria play an important role in maintaining a healthy heart and regulating various cellular processes, including adenosine triphosphate (ATP), which is utilized as energy in the heart through oxidative phosphorylation (OXPHOS) (Chaudhary et al., 2011). The free radical theory of aging proposed 60 years ago posits that the activity of reactive oxygen species (ROS) is the important determinant of lifespan and induction of cardiac diseases (Harman, 1956). In general, ROS are generated by multiple enzymes and organelles in the cell, such as NADPH oxidase at the plasma membrane, lipid oxidation in peroxisomes, and especially OXPHOS in mitochondria (Dai et al., 2012). Appropriate levels of mitochondrial $\mathrm{H}_{2} \mathrm{O}_{2}$ emission, which is regarded as a physiological ROS marker, are essential in regulating a cellular redox environment of cells and mitochondrial function (Jones, 2008). However, excessive ROS emissions, such as $\mathrm{H}_{2} \mathrm{O}_{2}$, can induce mitochondrial and cellular dysfunctions, which lead to impaired mitochondrial DNA (Martindale and Holbrook, 2002), causing senescence in many cell types (Ben-Porath and Weinberg, 2005). Ex-
${ }^{*}$ Corresponding author: Hyo-Bum Kwak (iD https://orcid.org/0000-0003-0451-4554 Department of Kinesiology, Inha University, 100 Inha-ro, Nam-gu, Incheon 22212, Korea

Tel: +82-32-860-8183, Fax: +82-32-860-8188, E-mail: kwakhb@inha.ac.kr

Received: October 3, 2018 / Accepted: November 3, 2018
This is an Open Access article distributed under the terms of the Creative Commons Attribution Non-Commercial License (http://creativecommons.org/licenses/by-nc/4.0/) which permits unrestricted non-commercial use, distribution, and reproduction in any medium, provided the original work is properly cited. 
cessive mitochondrial $\mathrm{H}_{2} \mathrm{O}_{2}$ emission has also been related to aging (Bejma et al., 2000; Kuka et al., 2013; Petrosillo et al., 2009).

The $\mathrm{Ca}^{2+}$ signals in mitochondria regulate key cellular functions, such as energy production, by regulating mitochondrial enzymes like pyruvate dehydrogenase, isocitrate dehydrogenase, and alpha-ketoglutarate dehydrogenase in the tricarboxylic acid cycle (Denton et al., 1978; Robb-Gaspers et al., 1998), and cell death (Williams et al., 2013). In addition, the transport of $\mathrm{Ca}^{2+}$ across the inner mitochondrial membrane is an essential signaling pathway for cellular metabolic functions (Lemasters et al., 2009). However, dysregulated $\mathrm{Ca}^{2+}$ cycling excessively increases the production of mitochondrial ROS and stimulates mitochondrial $\mathrm{Ca}^{2+}$ overload, resulting in increased opening of susceptible mitochondrial permeability transition pores (mPTPs) (De Stefani et al., 2016), which preludes cell death (Panel et al., 2018). Aging reportedly induces mitochondrial $\mathrm{Ca}^{2+}$ overload, as evidenced by $\mathrm{Ca}^{2+}$ overload-induced increase in the opening of mPTPs in aged rat heart compared with young rat heart (Hunter et al., 2012).

Taken together, the data suggest that mitochondrial dysfunction could occur with aging, which would eventually induce age-related cardiac dysfunction. However, most of the previous studies regarding aging-induced alteration of mitochondrial function in cardiac muscle have been confined to isolated mitochondria, in which only mitochondrial function and structure could be impaired (Picard et al., 2011). Therefore, the purpose of this study was to determine the effects of aging on mitochondrial OXPHOS and mitochondrial function (e.g., mitochondrial $\mathrm{H}_{2} \mathrm{O}_{2}$ emission and $\mathrm{Ca}^{2+}$ retention capacity) in permeabilized rat heart. We hypothesized that mitochondrial OXPHOS and mitochondrial function are dysregulated by senescence in rat cardiac muscle.

\section{MATERIALS AND METHODS}

\section{Animals}

Male Fischer 344 rats were housed in a temperature- and humidity-controlled $\left(20^{\circ} \mathrm{C} \pm 2^{\circ} \mathrm{C}\right)$ room with a 12-hr light (8:00 a.m. to 7:59 p.m.) and dark (8:00 p.m. to 8:00 a.m.) cycle. Rats were given time to adapt to the environment for approximately 1 week in the animal cages prior to beginning the experiment. Food and water were provided ad libitum throughout the study period. The rats were divided into the VYS, YS, MS, and OS groups ( $\mathrm{n}=10$ per group). The experimental procedures were performed in accordance with the animal care guidelines of the National Institutes of Health and the Korean Academy of Medical Sciences.

\section{Preparation of tissue and permeabilized muscle fiber} bundles

Rats were anesthetized using ether prior to sacrifice. Hearts were extracted, weighed, and dissected to obtain the left ventricle (LV). Approximately $2 \mathrm{mg}$ of $\mathrm{LV}$ tissue was permeabilized to assess mitochondrial functions. The other samples were snap-frozen in liquid nitrogen and stored at $-80^{\circ} \mathrm{C}$ freezer until further analysis.

Permeabilized muscles in $\mathrm{LV}$ were placed in ice-cold buffer $\mathrm{X}$ containing $50 \mathrm{mM}$ MES, $7.23 \mathrm{mM} \mathrm{K} \mathrm{EGTA}_{2} 2.77 \mathrm{mM} \mathrm{CaK}$ EGTA, $20 \mathrm{mM}$ imidazole, $0.5 \mathrm{mM}$ dithiothreitol, $20 \mathrm{mM}$ taurine, $5.7 \mathrm{mM}$ ATP, $14.3 \mathrm{mM}$ phosphocreatine, and $6.56 \mathrm{mM} \mathrm{MgCl}_{2}$ $6 \mathrm{H}_{2} \mathrm{O}(\mathrm{pH}, 7.1 ; 295 \mathrm{mOsm})$ and trimmed of fat and connective tissue. The small muscle fiber bundles were separated along the longitudinal axis and treated with $100-\mu \mathrm{g} / \mathrm{mL}$ saponin to increase the permeability of the sarcolemmal membrane while keeping mitochondrial membrane intact for $30 \mathrm{~min}$. The permeabilized LV fiber bundles were washed in ice-cold buffer $\mathrm{Z}$ and added to $50 \mu \mathrm{M}$ EGTA (washing buffer) containing $105 \mathrm{mM}$ K-MES, 30 $\mathrm{mM} \mathrm{KCl}, 10 \mathrm{mM} \mathrm{KH}_{2} \mathrm{PO}_{4}, 5 \mathrm{mM} \mathrm{MgCl}-6 \mathrm{H}_{2} \mathrm{O}$, and $0.5 \mathrm{mM}$ $\mathrm{mg} / \mathrm{mL}$ bovine serum albumin $(\mathrm{pH}, 7.1)$ for at least $15 \mathrm{~min}$ in a shaker and remained in buffer $\mathrm{Z}$ on a rotator apparatus at $4^{\circ} \mathrm{C}$ until analyzed. The permeabilized LV fiber bundles were used for measurements of mitochondrial $\mathrm{H}_{2} \mathrm{O}_{2}$ emission and $\mathrm{Ca}^{2+}$ retention capacity.

\section{Mitochondrial $\mathrm{H}_{2} \mathrm{O}_{2}$ emission}

Mitochondrial $\mathrm{H}_{2} \mathrm{O}_{2}$ emission was measured in buffer $\mathrm{Z}$ at $37^{\circ} \mathrm{C}$ $(\Delta \mathrm{F} / \mathrm{min})$ during state 4 respiration $(10-\mu \mathrm{g} / \mathrm{mL}$ oligomycin) by continuously monitoring the oxidation of Amplex Red (excitation/emission wavelengths $=567 / 587 \mathrm{~nm}$ ) using a SPEX Fluoromax 4 spectrofluorometer (HORIBA, Edison, NJ, USA). The procedure used 2-mg LV muscle fiber, $10 \mu \mathrm{M}$ Amplex Red, 1.5 $\mathrm{U} / \mathrm{mL}$ horseradish peroxidase (HRP), $10-\mu \mathrm{g} / \mathrm{mL}$ oligomycin settings, and $5 \mathrm{mM}$ glutamate (complex I substrate) $+2 \mathrm{mM}$ malate (complex I substrate), $10 \mathrm{mM}$ succinate (complex II substrate), and $10 \mathrm{mM}$ glycerol-3 phosphate (lipid substrate). The $\mathrm{H}_{2} \mathrm{O}_{2}$ emission rate after removing the background value from each of the standard values (standard curve) was calculated from the slope of $\Delta \mathrm{F} / \mathrm{min}$ gradient values. After the experiment, the raw data of mitochondrial $\mathrm{H}_{2} \mathrm{O}_{2}$ emission were normalized using wet tissue weight. The rate of mitochondrial $\mathrm{H}_{2} \mathrm{O}_{2}$ emission was expressed as picomoles $/ \mathrm{min} / \mathrm{mg}$ wet tissue weight.

\section{Mitochondrial $\mathrm{Ca}^{2+}$ retention capacity}

Mitochondrial $\mathrm{Ca}^{2+}$ retention capacity was performed to assess 
the susceptibility of the mPTP opening as previously reported (Anderson et al., 2011) with modification. Briefly, after LV tissues were separated, permeabilized with saponin, and washed with washing buffer (buffer Z containing $50 \mu \mathrm{M}$ EGTA), overlaid traces of changes in $\mathrm{Ca}^{2+}$ induced fluorescence by Calcium Green- $5 \mathrm{~N}$ were measured continuously $(\Delta \mathrm{F} / \mathrm{min})$ at $37^{\circ} \mathrm{C}$ during state 4 condition $(10-\mu \mathrm{g} / \mathrm{mL}$ oligomycin) using the aforementioned Spex Fluormax 4 spectrofluorometer (HOROBA, Edison, NJ, USA). After establishing background $\Delta \mathrm{F} / \mathrm{min}(1 \mu \mathrm{M}$ Calcium Green- $5 \mathrm{~N}$ $80 \mu \mathrm{M}$ EGTA, $5 \mu \mathrm{M}$ glutamate, and $2 \mu \mathrm{M}$ malate), the reaction was initiated by the addition of $\mathrm{Ca}^{2+}$ pulses $(30 \mu \mathrm{M})$, with excitation and emission wavelengths of 506 (excitation wavelength) and 532 (emission wavelength) nm, respectively. After completion of the experiment, the level of mitochondrial $\mathrm{Ca}^{2+}$ retention capacity was normalized by wet tissue weight. Total mitochondrial $\mathrm{Ca}^{2+}$ retention capacity was expressed as picomoles $/ \mathrm{min} / \mathrm{mg}$ wet tissue weight.

\section{Western immunoblot for electron transport chain (ETC) composition in mitochondria}

Frozen LV tissues were homogenized with lysis buffer containing $50 \mathrm{mM}$ Tris/ $\mathrm{HCl}(\mathrm{pH}, 7.4), 150 \mathrm{mM} \mathrm{NaCl}, 10 \%$ glycerol, $1 \%$ Triton X-100, $1.5 \mathrm{mM} \mathrm{MgCl} 2 \cdot 6 \mathrm{H}_{2} \mathrm{O}, 1 \mathrm{mM}$ EGTA, $1 \mathrm{mM}$ PMSF, $1 \mathrm{mM} \mathrm{Na}_{2} \mathrm{VO}_{4}$, and $100 \mathrm{mM} \mathrm{NaF}$ in an OMNI TH homogenizer (OMNI International, NW Kennesaw, GA, USA). The homogenized tissue was centrifuged at 14,000 rpm for 30 min. Protein concentration was analyzed using a colorimetric protein assay kit (Bio-Rad, Hercules, CA, USA). Protein $(20 \mu \mathrm{g})$ was heated at $35^{\circ} \mathrm{C}$ for $5 \mathrm{~min}$ and separated by $12 \%$ sodium dodecyl sulfate-polyacrylamide gel electrophoresis. After loading for $2 \mathrm{hr}$ at $110 \mathrm{~V}$, the loaded proteins were electro-transferred for $1 \mathrm{hr}$ at $400 \mathrm{~mA}$ onto a nitrocellulose membrane. After staining with Ponceau S (Sigma-Aldrich, St. Louis, MO, USA) to verify equal loading and transfer of proteins to the membranes, the membranes were blocked with 5\% skim milk in Tris-buffered saline containing $0.1 \%$ Tween- 20 (TBS-T) for $2 \mathrm{hr}$. The membranes were incubated overnight at $4{ }^{\circ} \mathrm{C}$ in primary antibody diluted 1:1,000 in TBS-T for recognition of specific target proteins of total OXPHOS rodent antibody cocktail (Abcam, Cambridge, MA, USA), which included the following: complex I (NADH dehydrogenase (ubiquinone) 1 beta subcomplex subunit 8, NDUFB8, $20 \mathrm{kDa}$ ), complex II (succinate dehydrogenase (ubiquinone) iron-sulfur subunit, SDHB, $30 \mathrm{kDa}$ ), complex III (cytochrome b-c1 complex subunit 2, UQCRC2, $48 \mathrm{kDa}$ ), complex IV (cytochrome c oxidase subunit 2, MTCO2, $40 \mathrm{kDa}$ ), and complex V
(ATP synthase subunit alpha, ATP5A, $55 \mathrm{kDa}$ ), with $\beta$-actin (Santa Cruz Biotechnology, Dallas, TX, USA) used as the loading control. Subsequently, membranes were washed with TBS-T and incubated in a 1:3,000 dilution of HRP-conjugated secondary anti-mouse antibody (Santa Cruz Biotechnology) for $1 \mathrm{hr}$ at room temperature. Following three washes in TBS-T, band detection was performed using the enhanced chemiluminescence detection kit (Thermo Fisher Scientific, Waltham, MA, USA). To compare the relative expression of proteins, the detected bands were calculated densitometrically using Image-Pro Plus software (Media Cybernetics, Bethesda, MD, USA).

\section{Statistical analyses}

Statistical analyses were performed using one-way analysis of variance followed by Tukey post hoc test to assess mean differences among groups for aging effects. The results are expressed as the mean \pm standard error of the mean. The statistical significance level was set at $P<0.05$.

\section{RESULTS}

\section{Effect of aging on body weight and heart mass}

The effects of aging on body weight, heart weight, and the heart mass/body weight ratio were assessed. The results are presented in Table 1. During aging, increased body weight was found in the OS group compared with the VYS, YS, and MS groups. In addition, heart mass was significantly elevated in the YS, MS, and OS groups compared with the VYS group $(P<0.05)$ (Table 1$)$. Importantly, the heart mass/body weight ratio, which is the surrogate of pathophysiological aging of the heart, was significantly decreased in the OS group compared with the VYS and YS groups $(P<0.05)$ (Table 1).

Table 1. Effects of aging on body weight, heart weight, and the heart-to-body weight ratio

\begin{tabular}{llll}
\hline Group & \multicolumn{1}{c}{$\begin{array}{c}\text { Body mass } \\
(\mathrm{g})\end{array}$} & $\begin{array}{c}\text { Heart mass } \\
(\mathrm{mg})\end{array}$ & $\begin{array}{c}\text { Heart mass/body mass } \\
(\mathrm{mg} / \mathrm{g})\end{array}$ \\
\hline WS & $112.00 \pm 8.96$ & $390.01 \pm 27.09$ & $3.50 \pm 0.07$ \\
YS & $308.62 \pm 5.61$ & $810.88 \pm 12.50^{\mathrm{a})}$ & $2.63 \pm 0.04^{\mathrm{a})}$ \\
MS & $301.57 \pm 15.66$ & $841.51 \pm 27.06^{\mathrm{a})}$ & $2.81 \pm 0.09^{\mathrm{a})}$ \\
OS & $367.00 \pm 12.27^{\mathrm{a}, \mathrm{b}, \mathrm{c})}$ & $874.77 \pm 34.63^{\mathrm{a})}$ & $2.41 \pm 0.08^{\mathrm{a}, \mathrm{c})}$ \\
\hline
\end{tabular}

Values are presented as mean \pm standard error of the mean.

VYS, very young sedentary group; YS, young sedentary group; MS, middle-aged sedentary group; $\mathrm{OS}$, old sedentary group.

${ }^{\text {a) } P}<0.05$ compared with VYS. ${ }^{b} P<0.05$ compared with $Y S$. ${ }^{\text {cl }} P<0.05$ compared with MS. 


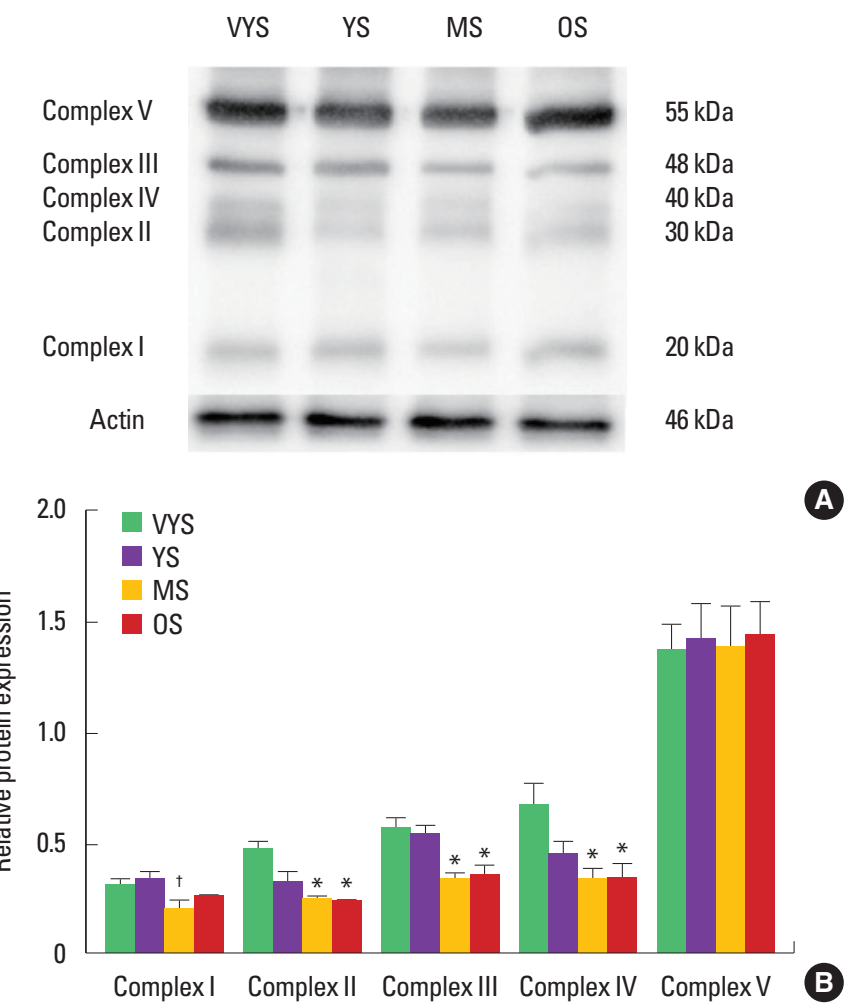

Fig. 1. Effect of aging on protein levels of mitochondrial electron transport chain complexes in the left ventricle (LV) in the very young sedentary (VYS), young sedentary (YS), middle-aged sedentary (MS), and old sedentary (OS) groups. (A) Representative immunoblot bands of mitochondrial electron transport chain protein expression in the LV. (B) Quantification of relative electron transport chain protein expression after normalization with actin. The results are presented as the mean \pm standard error of the mean. ${ }^{*} P<0.05$ compared with $\mathrm{VYS} .{ }^{\dagger} P<0.05$ compared with YS.

\section{Effect of aging on protein expression of mitochondrial ETC complexes}

Mitochondrial ETC complexes I-V were measured in rat heart tissues. The mitochondrial contents were decreased in the MS and OS groups compared with the VYS group, demonstrating that the protein levels of complex II (succinate dehydrogenase), III (cytochrome c reductase), and IV (cytochrome c oxidase) were significantly lowered in the MS and OS groups compared with that in the VYS group $(P<0.05)$ (Fig. 1). Complex V (ATP synthase) was not affected by aging.

\section{Effect of aging on mitochondrial $\mathrm{H}_{2} \mathrm{O}_{2}$ emission}

Mitochondrial $\mathrm{H}_{2} \mathrm{O}_{2}$ emission was measured using glutamate+ malate (GM), succinate (S), and glycerol-3-phosphate (G3P) as substrates (Fig. 2). Mitochondrial $\mathrm{H}_{2} \mathrm{O}_{2}$ emission was increased only in the YS group compared with the VYS group using GM $(1.05 \pm 0.32$ vs. $3.38 \pm 0.66, P<0.05)$ (Fig. 2). In the next stage
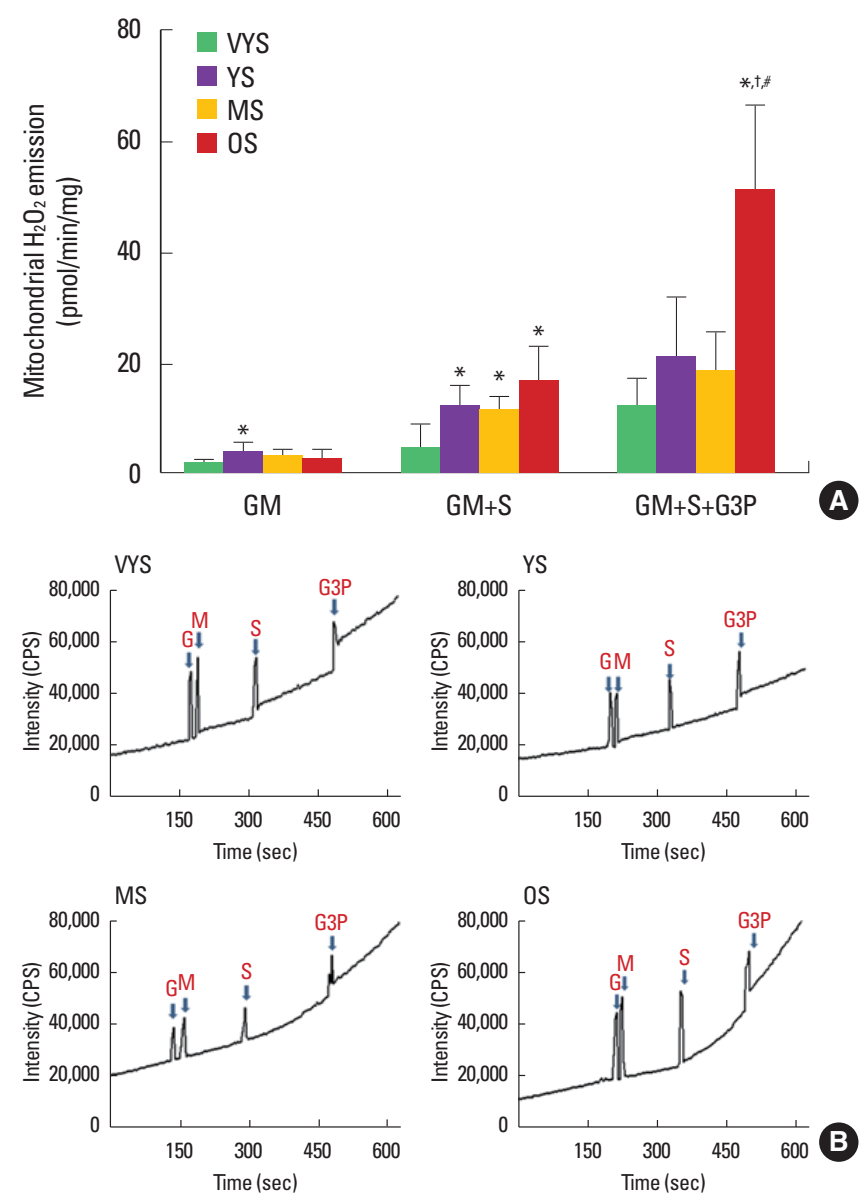

Fig. 2. Effect of aging on mitochondria $\mathrm{H}_{2} \mathrm{O}_{2}$ emission in the left ventricle in the very young sedentary (VYS), young sedentary (YS), middle-aged sedentary (MS), and old sedentary (OS) groups. The mitochondrial $\mathrm{H}_{2} \mathrm{O}_{2}$ emission rate after removing the background value from each of the standard values was calculated from the slope of $\Delta \mathrm{F} / \mathrm{min}$ gradient values. The $\Delta \mathrm{F} / \mathrm{min}$ was determined in response to $5 \mathrm{mM}$ glutamate (G) and $2 \mathrm{mM}$ malate (M), $10 \mathrm{mM}$ succinate $(\mathrm{S})$, and $10 \mathrm{mM}$ glycerol 3-phosphate (G3P). (A) The rate of mitochondrial $\mathrm{H}_{2} \mathrm{O}_{2}$ emission. (B) Representative experimental traces of mitochondria $\mathrm{H}_{2} \mathrm{O}_{2}$ emissions in permeabilized cardiac myofibers. The results are presented as the mean \pm standard error of the mean. ${ }^{*} P<0.05$ compared with VYS. ${ }^{\dagger} P<0.05$ compared with $Y S .{ }^{*} P<0.05$ compared with MS.

$(\mathrm{GM}+\mathrm{S})$, aging-induced mitochondrial $\mathrm{H}_{2} \mathrm{O}_{2}$ was observed in the OS group compared with the VYS group ( $4.03 \pm 1.54$ vs. $16.42 \pm$ $2.13, P<0.05$ ) (Fig. 2). In addition, excessive $\mathrm{H}_{2} \mathrm{O}_{2}$ emission supported by $\mathrm{GM}+\mathrm{S}+\mathrm{G} 3 \mathrm{P}$ was found in the OS group compared with the VYS, YS, and MS groups $(11.36 \pm 1.92,20.71 \pm 3.88$, $18.11 \pm 2.63$ vs. $50.82 \pm 5.55$, respectively; $P<0.05$ ) (Fig. 2).

\section{Effect of aging on mitochondrial $\mathrm{Ca}^{2+}$ retention capacity}

The mitochondrial $\mathrm{Ca}^{2+}$ retention capacity was measured in permeabilized rat heart tissues. $\mathrm{Ca}^{2+}$ retention was significantly 

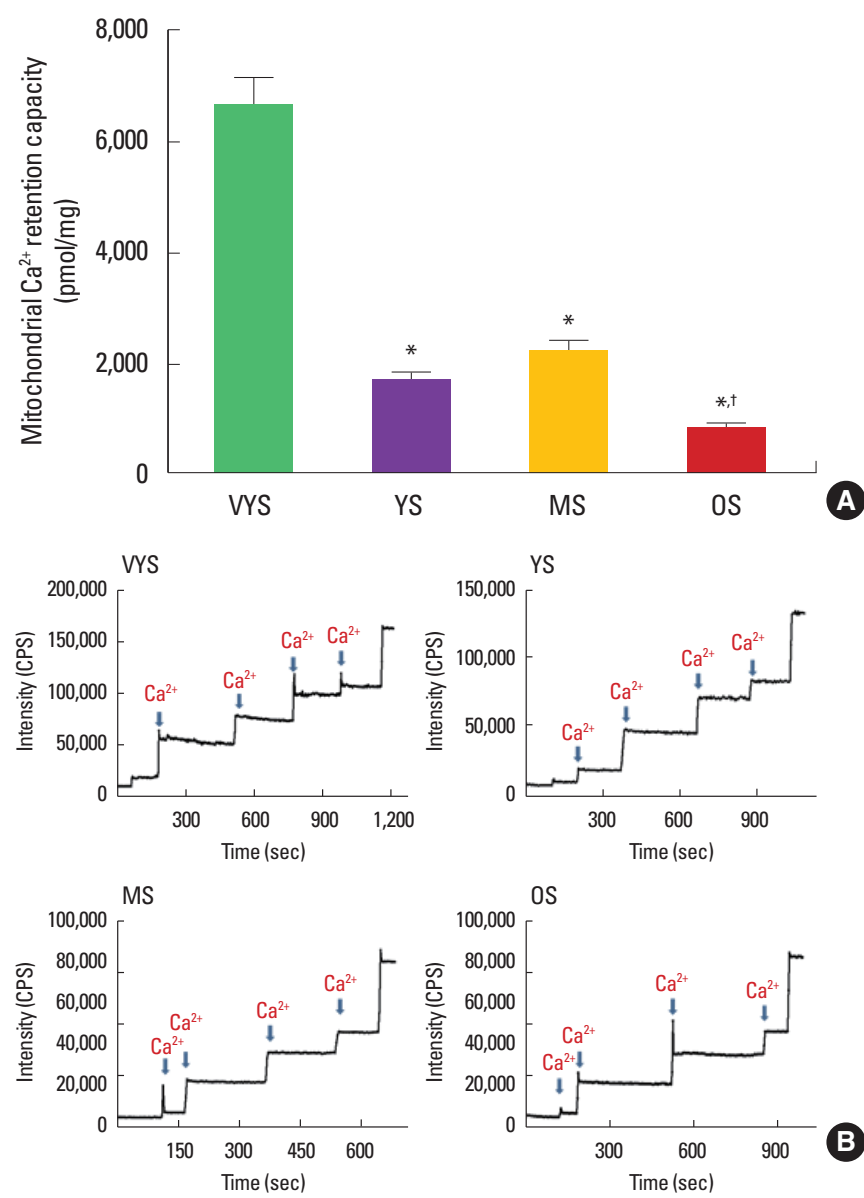

Fig. 3. Effect of aging on mitochondria $\mathrm{Ca}^{2+}$ retention capacity in the left ventricle in the very young sedentary (VYS), young sedentary (YS), middle-aged sedentary (MS), and old sedentary (OS) groups; $\downarrow$ : $\mathrm{Ca}^{2+}$ infusion. (A) Quantified amount of total mitochondrial $\mathrm{Ca}^{2+}$ retention capacity. (B) Representative experimental traces showing increases in calcium green 5-N fluorescence in response to $1 \mu \mathrm{M} \mathrm{Ca}^{2+}$. The results are presented as the mean \pm standard error of the mean. ${ }^{*} P<0.05$ compared with VYS. ${ }^{\dagger} P<0.05$ compared with MS.

lower in the OS group compared with the VYS and MS groups $(6,590.53 \pm 544.44$ vs. $786.53 \pm 122.91,2,215.14 \pm 163.46$ vs. $786.53 \pm 122.91$, respectively; $P<0.05$ ) (Fig. 3), suggesting that $\mathrm{Ca}^{2+}$ overload-induced mPTP opening could be activated by aging.

\section{DISCUSSION}

There are two major findings. First, aging triggered the reduced protein levels of ETC complexes in the cardiac muscles. Second, mitochondrial dysfunction $\left(\mathrm{H}_{2} \mathrm{O}_{2}\right.$ emission and $\mathrm{Ca}^{2+}$ retention capacity) occurred as aging progressed in the permeabilized rat cardiac muscle, showing that mitochondrial $\mathrm{H}_{2} \mathrm{O}_{2}$ emission was excessively increased and mitochondrial $\mathrm{Ca}^{2+}$ retention capacity was progressively decreased with aging. These findings support the hypothesis that aging induces the dysregulation of mitochondrial OXPHOS and dysfunction in rat cardiac muscle.

Aging decreased the protein levels of mitochondrial ETC complexes II-IV, which are markers of mitochondrial contents, resulting in reduced energy production (Fig. 1). Age-dependent decrease in cardiac mitochondrial OXPHOS was previously associated with the decline in maximal ADP-stimulated $\mathrm{O}_{2}$ respiration (state 3) due to diminished activity of complex I and IV in mitochondrial ETC (Navarro and Boveris, 2007). In addition, reduced energy production in cardiac mitochondria contributes to increased ROS, increased mutations and deletions in the mitochondrial genome, and impaired regulation of mitochondrial biogenesis (Navarro and Boveris, 2007; Tatarková et al., 2011). Indeed, in this study, aging-induced decreases in protein levels of mitochondrial complexes were observed in complex II, III, and IV, suggesting that energy production was decreased by aging.

We also demonstrated that aging induced the mitochondria-mediated production of ROS, such as $\mathrm{H}_{2} \mathrm{O}_{2}$ emission in rat cardiac muscle. Previous studies have associated aging with increased mitochondrial $\mathrm{H}_{2} \mathrm{O}_{2}$ emission (Bejma et al., 2000; Kuka et al., 2013; Petrosillo et al., 2009). Consistent with the prior findings, we presently observed that elevated mitochondrial $\mathrm{H}_{2} \mathrm{O}_{2}$ emission in aging cardiac muscle compared with young cardiac muscle (Fig. 2). Specifically, the current results demonstrated that mitochondrial $\mathrm{H}_{2} \mathrm{O}_{2}$ emission was significantly increased in $\mathrm{GM}+\mathrm{S}$ (complex II substrate) and GM+S+G3P (lipid substrate) in OS group, suggesting that this aging-induced increase in mitochondrial ROS could reuslt in the accumulation of damaged proteins, which could play a major role in generating aging-related tissue dysfunction (Balaban et al., 2005).

Finally, we also observed that mitochondrial $\mathrm{Ca}^{2+}$ retention capacity was significantly reduced by aging. Mitochondrial $\mathrm{Ca}^{2+}$ is essential in regulating ATP production by controlling OXPHOS of the heart (Kohlhaas and Maack, 2013). However, aging can exacerbate mitochondrial $\mathrm{Ca}^{2+}$ regulation, and progressively impair the myocardial $\mathrm{Ca}^{2+}$ transport system, $\mathrm{Ca}^{2+}$ storage capacities, and contractile function by altering cytosolic $\mathrm{Ca}^{2+}$ handling (Panel et al., 2018), which are associated with mitochondrial $\mathrm{Ca}^{2+}$ overload. Consistent with this recent study, we also obbserved diminshed mitochondrial $\mathrm{Ca}^{2+}$ retention capacity in aging cardiac muscle (Fig. 3), which resulted in more prevalent mPTP opening, compared with that in young cardiac muscle.

The collective data demonstrate that aging dysregulates OXPHOS, with lower protein levels of complex II-IV in the ETC in 
the cardiac muscle. In addition, aging is associated with induced mitochondrial dysfunction, with increased mitochondrial $\mathrm{H}_{2} \mathrm{O}_{2}$ emission and decreased mitochondrial $\mathrm{Ca}^{2+}$ retention capacity in permeabilized cardiac muscle fiber of aging rats. These findings demonstrate a pivotal role of aging in dysregulation of mitochondrial OXPHOS and mitochondrial function.

\section{CONFLICT OF INTEREST}

No potential conflict of interest relevant to this article was reported.

\section{ACKNOWLEDGMENTS}

This work was supported by the Ministry of Education of the Republic of Korea and the National Research Foundation of Korea (NRF-2016S1A5A8018954) and World Class Smart Lab at Inha University.

\section{REFERENCES}

Anderson EJ, Rodriguez E, Anderson CA, Thayne K, Chitwood WR, Kypson AP. Increased propensity for cell death in diabetic human heart is mediated by mitochondrial-dependent pathways. Am J Physiol Heart Circ Physiol 2011;300:H118-124.

Balaban RS, Nemoto S, Finkel T. Mitochondria, oxidants, and aging. Cell 2005;120:483-495.

Bejma J, Ramires P, Ji LL. Free radical generation and oxidative stress with ageing and exercise: differential effects in the myocardium and liver. Acta Physiol Scand 2000;169:343-351.

Ben-Porath I, Weinberg RA. The signals and pathways activating cellular senescence. Int J Biochem Cell Biol 2005;37:961-976.

Bursi F, Weston SA, Redfield MM, Jacobsen SJ, Pakhomov S, Nkomo VT, Meverden RA, Roger VL. Systolic and diastolic heart failure in the community. JAMA 2006;296:2209-2216.

Chaudhary KR, El-Sikhry H, Seubert JM. Mitochondria and the aging heart. J Geriatr Cardiol 2011;8:159-167.

Dai DF, Rabinovitch PS. Cardiac aging in mice and humans: the role of mitochondrial oxidative stress. Trends Cardiovasc Med 2009;19:213220.

Dai DF, Rabinovitch PS, Ungvari Z. Mitochondria and cardiovascular aging. Circ Res 2012;110:1109-1124.

De Stefani D, Rizzuto R, Pozzan T. Enjoy the trip: calcium in mitochondria back and forth. Annu Rev Biochem 2016;85:161-192.

Denton RM, Richards DA, Chin JG. Calcium ions and the regulation of
$\mathrm{NAD}^{+}$-linked isocitrate dehydrogenase from the mitochondria of rat heart and other tissues. Biochem J 1978;176:899-906.

Gerhard-Herman MD, Gornik HL, Barrett C, Barshes NR, Corriere MA, Drachman DE, Fleisher LA, Fowkes FG, Hamburg NM, Kinlay S, Lookstein R, Misra S, Mureebe L, Olin JW, Patel RA, Regensteiner JG, Schanzer A, Shishehbor MH, Stewart KJ, Treat-Jacobson D, Walsh ME. 2016 AHA/ACC guideline on the management of patients with lower extremity peripheral artery disease: executive summary: a report of the american college of cardiology/american heart association task force on clinical practice guidelines. J Am Coll Cardiol 2017;69: 1465-1508.

Harman D. Aging: a theory based on free radical and radiation chemistry. J Gerontol 1956;11:298-300.

Hunter JC, Machikas AM, Korzick DH. Age-dependent reductions in mitochondrial respiration are exacerbated by calcium in the female rat heart. Gend Med 2012;9:197-206.

Jones DP. Radical-free biology of oxidative stress. Am J Physiol Cell Physiol 2008;295:C849-868.

Karavidas A, Arapi SM, Pyrgakis V, Adamopoulos S. Functional electrical stimulation of lower limbs in patients with chronic heart failure. Heart Fail Rev 2010;15:563-579.

Kirkwood TB. Understanding the odd science of aging. Cell 2005;120:437447.

Kohlhaas M, Maack C. Calcium release microdomains and mitochondria. Cardiovasc Res 2013;98:259-268.

Kuka S, Tatarkova Z, Racay P, Lehotsky J, Dobrota D, Kaplan P. Effect of aging on formation of reactive oxygen species by mitochondria of rat heart. Gen Physiol Biophys 2013;32:415-420.

Lemasters JJ, Theruvath TP, Zhong Z, Nieminen AL. Mitochondrial calcium and the permeability transition in cell death. Biochim Biophys Acta 2009;1787:1395-1401.

Martindale JL, Holbrook NJ. Cellular response to oxidative stress: signaling for suicide and survival. J Cell Physiol 2002;192:1-15.

Navarro A, Boveris A. The mitochondrial energy transduction system and the aging process. Am J Physiol Cell Physiol 2007;292:C670-686.

Olsen J, Willaing I, Ladelund S, Jørgensen T, Gundgaard J, Sørensen J. Cost-effectiveness of nutritional counseling for obese patients and patients at risk of ischemic heart disease. Int J Technol Assess Health Care 2005;21:194-202.

Panel M, Ghaleh B, Morin D. Mitochondria and aging: a role for the mitochondrial transition pore? Aging Cell 2018;17:e12793.

Petrosillo G, Matera M, Moro N, Ruggiero FM, Paradies G. Mitochondrial complex I dysfunction in rat heart with aging: critical role of reactive oxygen species and cardiolipin. Free Radic Biol Med 2009;46:88-94.

Picard M, Taivassalo T, Gouspillou G, Hepple RT. Mitochondria: isola- 
tion, structure and function. J Physiol 2011;589(Pt 18):4413-4421.

Robb-Gaspers LD, Burnett P, Rutter GA, Denton RM, Rizzuto R, Thomas AP. Integrating cytosolic calcium signals into mitochondrial metabolic responses. EMBO J 1998;17:4987-5000.

Tatarková Z, Kuka S, Račay P, Lehotský J, Dobrota D, Mištuna D, Kaplán

P. Effects of aging on activities of mitochondrial electron transport chain complexes and oxidative damage in rat heart. Physiol Res 2011; 60:281-289.

Williams GS, Boyman L, Chikando AC, Khairallah RJ, Lederer WJ. Mitochondrial calcium uptake. Proc Natl Acad Sci U S A 2013;110:1047910486 . 